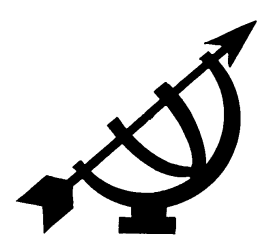

\title{
Drug testing in American schools
}

C.J. Russo

University of Dayton

Ohio, USA

E-mail: russo@keiko.udayton.edu
R.D. Mawdsley

Cleveland State University

Ohio, USA

r.mawdsley@csuohio.edu

\section{I.J Oosthuizen}

Faculty of Education Sciences

Potchefstroom University for CHE

POTCHEFSTROOM

E-mail: sooijo@puknet.puk.ac.za

Abstract

Drug testing in American schools

As the use of illegal drugs has reached epidemic proportions in schools, educational leaders in the United States have turned to drug testing in attempting to maintain learner discipline. To this end, the United States Supreme Court has addressed the issue twice in the past eight years. In 1995, the Court permitted drug testing in Acton v. Vernonia School District 47J. More recently, in Board of Education of Independent School District No. 92 of Pottawatomie v. Earls (2002), the Court upheld suspicionless drug testing of learners who wished to participate in extracurricular activities.

Even though drug testing has yet to emerge as an issue in South Africa, Earls is significant for educational leaders and policy makers in South Africa since it involves concerns under the National Policy on Privacy. More specifically, under Items 20 and 21 of the South African National Policy on the Management of Drug Abuse (SA, 1996b) searches and drug testing should only be used where there is reasonable suspicion, the same standard applied by American courts. However, unlike the United States, the South African policy prohibits random searches and/or drug testing. Thus, due to constitutional and educational issues that drug testing raises, a timely discussion of this matter should be of interest to educational leaders and policy makers in South Africa. 
Opsomming

Die toetsing vir verbode middels in Amerikaanse skole

Leerdermisbruik van verbode verdowingsmiddels in Amerikaanse skole het sulke afmetings aangeneem dat die toets vir die gebruik daarvan in Amerika sterk op die voorgrond getree het. Die hele kwessie is gedurende die afgelope agt jaar twee maal in die Amerikaanse Hooggeregshof behandel. In 1995 het dié hof in Acton v. Vernonia die toets van verbode middels onder leerders toegelaat. Meer onlangs, in Board of Education of Independent School District No. 92 of Pottawatomie v. Earls (2002) het die hof die groenlig gegee vir die sogenaamde blinde toetse van leerders wat aan buitemuurse bedrywighede deelneem.

Hoewel die hele kwessie van verdowingsmiddeltoetse nog nie sterk op die voorgrond getree het in Suid-Afrika nie, is Earls tog betekenisvol vir onderwysleiers en beleidmakers in Suid-Afrika. Deursoeking word beleidmatig betrek in die nasionale beleid oor die hantering van verbode middels. Daarvolgens word deursoeking slegs toegelaat op grond van 'n redelike vermoede. Anders as in die VSA is blinde deursoeking nie toelaatbaar nie.

\section{Introduction ${ }^{1}$}

The experiences of Olympic and other international athletes (IOC Strips '02 Ski Medals, 2003 WL 60838206; Drug Testers Have Designs on New Steroids, 2003 WL 15464675) reveal that random drug testing is accepted as a common practice throughout the world. Moreover, as the use of illegal drugs has reached epidemic proportions in schools, educational leaders in the United States have turned to random drug testing in attempting to maintain learner discipline. Drug testing has become such an issue that the United States Supreme Court has addressed the issue twice in the past eight years. In 1995, the Court permitted drug testing in Acton v. Vernonia School District 47J. More recently, in Board of Education of Independent School District No. 92 of Pottawatomie v. Earls (Earls) (2002), the Court upheld suspicionless drug testing of learners who wished to participate in extracurricular activities.

As useful as drug testing may be in helping to preserve discipline in schools, it is an approach that is not without difficulties. In light of the challenges surrounding suspicionless (at random) drug testing, this article reviews relevant case law on the Fourth Amendment to the

$1 \quad$ Please refer to the Editorial note on p. 554. 
United States Constitution in school settings. The article pays particular attention to the search for and the suspicionless (at random) testing of drugs. In this regard special attention will be given to Earls v. Board of Education of Independent School District No. 92 of Pottawatonie since it is the Court's most recent pronouncement in this area. Further, even though drug testing has yet to emerge as an issue in South Africa, Earls is significant for educational leaders and policy makers in South Africa since it implicates concerns under the National Policy on Privacy. More specifically, under Items 20 and 21 of the South African National Policy on the Management of Drug Abuse (SA, 1996b) searches as well as drug testing should only be used where there is reasonable suspicion - which is similar to the standard applied by American courts. However, unlike the United States, the South African National Policy on the Management of Drug Abuse by Learners (SA,1996b) prohibits random (suspicionless) searches and/or drug testing. Thus, due to constitutional and educational issues that drug testing raises, a discussion of this timely matter should be of interest to educational leaders and policy makers in South Africa.

\section{Learner searches in terms of the Fourth Amendment of the US Constitution}

According to the Fourth Amendment of the United States Constitution (1789), "The right of the people to be secure in their persons, houses, papers, and effects, against unreasonable searches and seizures, shall not be violated ...". The Supreme Court first addressed the Fourth Amendment in a school setting in New Jersey v. T.L.O. (T.L.O.) (1985). When a fourteen year-old learner, identified as T.L.O., and a friend were accused of violating school rules by smoking cigarettes in a high school lavatory, the latter, who admitted to smoking, was not brought to the office for a search. Insofar as T.L.O. denied smoking and claimed that she did not smoke at all, the teacher who confronted her brought her to the assistant principal's office. On opening T.L.O.'s purse, since the assistant principal saw her cigarettes "in plain view," a term borrowed from criminal law, he removed them and accused her of lying. Continuing the search, the assistant principal discovered cigarette rolling papers, a small amount of marijuana, a pipe, a number of plastic bags, a substantial quantity of one dollar bills, an index card that appeared to be a list of learners who owed T.L.O. money, and two letters that implicated her in dealing marijuana. 
Once T.L.O. confessed to selling marijuana at her high school, a state trial court refused to suppress the evidence, adjudicated her as delinquent, and sentenced her to a year on probation (In re T.L.O., 1980). An intermediate appellate court affirmed the denial of the motion to suppress the search of T.L.O.'s purse, but vacated and remanded since neither the record nor the findings and conclusions below were sufficient to evaluate whether she knowingly and voluntarily waived her Fifth Amendment rights before confessing (In re T.L.O., 1982). The Supreme Court of New Jersey reversed in declaring that the search of T.L.O.'s purse violated the Fourth Amendment (In re T.L.O., 1983).

On appeal, the Supreme Court reversed in favour of the State of New Jersey. In holding that the Fourth Amendment's prohibition against unreasonable searches and seizures applies in public schools, the Court devised a two-part test to evaluate the legality of a search. "First, one must consider 'whether the ... action was justified at its inception;' second, one must determine whether the search as actually conducted was reasonably related in scope to the circumstances which justified the interference in the first place'" (T.L.O., 1985:341).

\subsection{Reasonable suspicion}

The Court further explained that a search is justified at its inception "when there are reasonable grounds for suspecting that the search will turn up evidence that the learner has violated or is violating either the law or the rules of the school" (T.L.O., 1985:342). A subjective measure based on specific facts, reasonable suspicion is significantly less than the probable cause standard that applies to the police. Insofar as school, also known as administrative, searches are designed to ensure school safety where there are generally large numbers of young people and reasonably few adults present, educators need only articulable justification in order to proceed.

A related concern in considering the totality of circumstances means that school officials may have to depend on the reliability of witnesses in determining whether to search. In assessing sufficiency of cause to conduct a search, courts consider such factors as the source of the information, a child's record, the seriousness and prevalence of the problem, and the urgency of making the search without delay. For example, courts have upheld searches based on information supplied by reliable learners (Commonwealth $v$. Snyder, 1992; In re L.A., 2001), parents (In re Joseph G., 1995), school employees (Cornfield v. Consolidated High Sch. Dist. No. 230, 
1993), or the police (In re D.E.M., 1999). At least one court upheld a search based on an odour emanating from a locker (People $v$. Lanthier, 1971) while another decided that a search was reasonable when placing a learner's book bag on a cabinet produced a metallic thud (Matter of Gregory M., 1993). Courts have also generally sustained searches of learners' cars (Anders ex rel. Anders v. Fort Wayne Community Schs., 2000; Covington County v. G.W., 2000; F.S.E. V. State, 1999), lockers (Zamora v. Pomeroy, 1981; Commonwealth v. Carey, 1990; In the Interest of Isiah B., 1993; Commonwealth v. Cass, 1998), and backpacks (In re F.B., 1999; In re Murray, 2000), for routine administrative purposes connected with a school's general welfare.

\subsection{Reasonable search}

Clarifying the second part of the test, in T.L.O., the Court added that "... a search will be permissible in its scope when the measures adopted are reasonably related to the objectives of the search and not excessively intrusive in light of the age and sex of the learner and the nature of the infraction" (342).

An even more intrusive form of searches involves strip searches. In apparently the earliest case, a federal trial court in Pennsylvania ruled that school officials and a city police chief were not entitled to a dismissal of Fourth Amendment claims filed by eight junior high school learners who were strip searched in an unsuccessful attempt to find a classmate's missing ring. The court left it for trial, which was either unreported or which did not occur, to evaluate whether the officials could be liable for the actions of their subordinates (Potts $v$. Wright, 1973). In a case that is more directly on point, a federal trial court in New York held that individualized suspicion was necessary for a strip search of fifth grade learners in an attempt to locate three dollars that were reported missing (Bellnier v. Lund, 1977).

Following T.L.O., the majority ${ }^{2}$ but not all ${ }^{3}$ cases have struck down searches for money with ${ }^{4}$ or without 5 personal items rather than

2 State ex rel. Galford v. Mark Anthony B. (1993); Kennedy v. Dexter Consol. Schs. (2000); Thomas ex rel. Thomas v. Roberts (2001); Bell v. Marseilles Elementary Sch. (2001).

$3 \quad$ Williams ex rel. Williams v. Ellington (1991); Cornfield by Lewis v. Consolidated High Sch. Dist. No. 230 (1993); Jenkins v. Tallaedga City Bd. of Educ. (1997); Cuesta v. School Bd. (2002).

$4 \quad$ State ex rel. Galford v. Mark Anthony B. (1993). 
drugs or some other form of contraband. Yet, in one case, the Seventh Circuit, an intermediate appellate federal court, upheld a strip search of a learner when looking for drugs even though his mother refused to consent to a pat down and he became visibly agitated when searched. The court was satisfied that since there was reasonable suspicion, school officials met both prongs of the T.L.O. test.

\subsection{Suspicionless drug testing}

Three years after T.L.O., a dispute from Indiana became the first school case on drug testing of learner athletes. After five baseball players had tested positive for marijuana, a school board instituted a policy calling for random drug testing for learner athletes and cheer leaders. The Seventh Circuit affirmed the validity of suspicionless testing on the basis that it was reasonable under the Fourth Amendment because school officials instituted sufficient safeguards to protect learner privacy (Schaill v. Tippecanoe County Sch. Corp., 1988). In upholding the policy, the court maintained that since learner athletes and cheer leaders gained enhanced prestige in the community, it was not unreasonable to require them to submit to drug testing.

\subsubsection{Vernonia School District 47J v. Acton}

Suspicionless drug testing can involve testing all or a random sample of a target population. In Vernonia School District $47 \mathrm{~J} \mathrm{~V}$. Acton (Vernonia) (1995), the Supreme Court, in its first case on point, upheld a school board policy that included both kinds of testing for participants in interscholastic sports. All participants were tested at the beginning of the season for their sport; thereafter $10 \%$ of learners were selected randomly during each week of the season. Whether the policy's goal in Vernonia, to deglamourise drug use, was consistent with its implementation is debatable. Despite evidence of drug abuse throughout the learner body, the policy was directed only at athletes who were at greater risk of immediate physical harm due to their activities. The list of drugs that officials tested for, amphetamines, marijuana, and cocaine, while harmful to athletes, omitted anabolic steroids, two substances that also pose a higher risk to learners. The omission of anabolic steroids suggests that the purpose of the testing policy was to get rid of drugs that affected the entire learner body. 
Perhaps Vernonia was more strategically formulated than policydriven since learner athletes were leaders of the drug culture in their school. Previously, in New Jersey v. T.L.O. (1985), the Court upheld individualized reasonable suspicion as the standard for learner searches. In Vernonia, the board selected a limited and more defensible fact situation involving athletics to assess the constitutionality of suspicionless drug testing. By limiting random drug testing to extracurricular athletics, the Vernonia Court created only a limited exception to the individualized suspicion testing of T.L.O.

In Vernonia, the Court addressed the question of individualized suspicion that it left unanswered in T.L.O. Acting in response to the perception of increased drug use among learners that began during the mid-to-late 1980s, the school board in Vernonia, Oregon, following up on parental concerns, instituted a drug testing policy for learner athletes. The board focused on learner athletes not only because they were leaders of the drug culture but also because there were incidents where at least two athletes were injured by the effects of drugs. The policy, which contained elaborate safeguards to protect the privacy rights of the learner athletes, required any learner who wished to try out for interscholastic athletic teams to submit to a urinalysis drug test.

When a seventh grade learner was suspended from interscholastic athletics because he and his parents refused to comply by signing a consent form for drug testing, they challenged his suspension, claiming that board officials violated his rights under the Fourth Amendment and the state constitution since there was no basis on which to believe that he ever used drugs. After a federal trial court in Oregon upheld the policy (Acton v. Vernonia Sch. Dist. 47J, 1992), the Ninth Circuit struck it down as unconstitutional (Acton $v$. Vernonia Sch. Dist. $47 \mathrm{~J}$, 1994). On further review, in Vernonia, the Supreme Court vacated and remanded the ruling of the Ninth Circuit.

The Supreme Court applied a three-part balancing test in affirming the constitutionality of the policy. First, the Court found that learners have a lesser expectation of privacy than ordinary citizens. The Court reasoned that learner athletes, in particular, experience diminished privacy because they are subject to physical examinations before becoming eligible to play and dress in open areas of locker rooms. Second, the Court indicated the urinalysis was minimally intrusive since it was coupled with safeguards that allowed little encroachment on the learners' privacy. Third, given the perception of increased drug use, the Court maintained that there was a 
significant need for the policy. On remand, the Ninth Circuit affirmed the decision of the trial court on the ground "... that the Oregon Supreme Court would not offer greater protection under the provisions of the Oregon Constitution in this case ...." (Acton $v$. Vernonia Sch. Dist. 47J, 1995).

Even after Acton, the circuit courts remained divided over suspicionless testing of learners involved in extracurricular activities including sports. For example, in a state court, the Supreme Court of Colorado struck down random testing of all learners in a school band, including those who participated for credit, on the basis that such learners had a greater expectation of privacy (Trinidad Sch. Dist. No. 1 v. Lopez, 1998). Further, the Seventh Circuit twice upheld suspicionless drug testing despite it expressed second thoughts about doing so but suggested that, but for its being bound by the precedent from the first case, it would have reached a different result (Todd v. Rush County Schs., 1998; Joy v. Penn Harris Madison Sch. Corp., 2000). Yet, the same court struck down drug and alcohol testing of a learner who was suspended for three days or more for fighting absent a nexus between use of the banned substances and violent behaviour (Willis v. Anderson Community Sch. Corp., 1998). Moreover, the Eighth Circuit originally upheld random testing but later vacated its judgment as moot when the learner moved out of the school district (Miller ex rel. Miller $v$. Wilkes, 1999). The Tenth Circuit, in a case that made its way to the Supreme Court as Board of Education of Independent School District No. 92 of Pottawatomie v. Earls (Earls) (2002) struck down random drug testing as unconstitutional and revealed how the disagreement between the circuits leaves educators within their jurisdictions without clear guidelines. In a case not involving a learner athlete, the Third Circuit affirmed that school officials did not violate the rights of a high school learner suspected of being on drugs when, pursuant to board policy, she was subjected to urinalysis testing (Hedges $v$. Musco, 2000). Even though the learner tested negative for drugs, the court affirmed that school officials did not violate the learner's Fourth-Amendment rights since testing was reasonable related to their objective of determining whether she used drugs. The court added that even though officials might have relied on less invasive means such as testing the learner's breath or saliva, rather than her urine, the test was not excessively intrusive. 


\subsubsection{Board of Education of Independent School District No. 92 of Pottawatomie v. Earls}

A school board in Oklahoma adopted a learner activities drug testing policy which required all middle and high school learners to consent to urinalysis testing for drugs in order to participate in any extracurricular activity. In practice, the policy applied only to learners who participated in competitive extracurricular activities sanctioned by the state's secondary schools' activities association. Learners and their parents filed suit under section 1983 alleging that the Policy violated their Fourth-Amendment rights because, in adopting it, the board neither identified a special need to test individuals who participated in extracurricular activities nor addressed a proven problem or offered to bring any benefits to learners or their school.

Relying on Vernonia, a federal trial court (Earls, 2000) granted the board's motion for summary judgment. However, a divided Tenth Circuit reversed in favour of the learner (Earls, 2001). On further review, in Board of Education of Independent School District No. 92 of Pottawatomie v. Earls (2002), a closely divided Supreme Court reversed in favour of the board.

The Court first considered the nature of the learners' alleged privacy interest, and pointed out that the privacy interests of public school learners are limited due to the need of officials to maintain discipline and safety. The Court also emphasized that individuals who participate in extracurricular activities voluntarily subject themselves to intrusions on their privacy, whereas their non-participating peers do not. As such, it was satisfied that given the limited privacy expectations of the learners who were affected by the policy, it was constitutionally acceptable.

Turning to the character of the intrusion that the policy imposed, the Court briefly reviewed key elements of the policy, noting that it included procedures that were virtually identical to those in Acton. If anything, it pointed out that this policy afforded even more protection because faculty members stood outside of closed restroom stalls, unlike Acton where males stood at a urinal, and produced urine samples which were then poured into different vials before being sent off for testing. The Court also acknowledged that the results were kept in separate confidential learner files that were released on a need-to-know basis and were not turned over to law enforcement officials. Finally, the Court noted that test results did not lead to the imposition of disciplinary or academic sanctions but only resulted in varying degrees of the loss of the privilege of participating in extra- 
curricular activities. Thus, the Court found that in light of the minimally intrusive way in which urine samples were collected along with the limited uses for the test results, the invasion into the privacy rights of learners was not significant.

As to the nature and immediacy of the board's concern and a policy's efficacy in meeting them, the Court recounted how it recognized the importance of governmental concern to prevent drug use, a problem that has not abated since Vernonia. In so doing the Court rebuffed the learners' claims that drug use was not a problem at the school by relying on specific evidence to the contrary offered by the board. The Court also indicated that it did not require a particularized or pervasive drug problem to be present before permitting government officials to conduct suspicionless testing. In light of the nationwide epidemic of drug use and the effectiveness of testing, he rejected the learners' argument that testing had to presumptively be based on individualized reasonable suspicion since this would be less intrusive. In concluding that drug testing was a reasonable effective means of addressing the board's legitimate concerns in preventing, deterring, and detecting drug use, the Court "express[ed] no opinion as to its wisdom (Earls, 2002:838)."

As controversies continue with regard to testing, a ruling from the Supreme Court of Indiana reflects the trend that the judiciary generally upholds testing for alcohol and drugs but not for other substances. More specifically, the court largely upheld a policy that permitted random testing of learners who participated in athletics, extracurricular, and co-curricular activities as well as on those wishing to drive to and from school for alcohol and other nontobacco related drugs because it merely barred individuals from participating in privileged activities in which they were portrayed as role models. In being satisfied that the policy was based on officials' valid interest in deterring learner drug abuse, the court decided that it did not violate the unreasonable searches and seizures clause in the state constitution (Linke v. Northwestern Sch. Corp., 2002). At the same time, the court decided that officials could not subject learners to nicotine testing because of their negligible interest in this regard.

\subsubsection{Some reflections on Earls}

In Earls, the Supreme Court avoided making educational policy by refusing to serve as the final arbiter of whether school boards should adopt random drug testing in response to drug use by learners. 
Even so, Earls opens the door for more school systems to impose random drug testing on extracurricular activities by extending the class of learners who can be tested randomly. To this end, drug testing in Earls includes not only the athletes who were approved for testing in Vernonia, but also the Future Farmers of America (FFA) and Future Homemakers of America (FHA) as well as the activities that the learner who filed suit was a member of the show choir, marching band, academic team, and National Honour Society.

In Earls, the Court seems to have eliminated the need it identified in Vernonia for a school board to demonstrate a special need to support its drug testing policy. Evidence in Vernonia based on learner drug use surveys and disciplinary referrals that reached epidemic proportions revealed not only a drug culture, but also that the athletes were the leaders of that culture. In Earls this level of evidence was reduced to teacher testimony that "learners appeared to be under the influence of drugs and that they had heard learners speaking openly about using drugs" (Earls, 2002:834-835). While the Court was convinced that this was "sufficient evidence to shore up the need for its drug testing programme", its refusal "to fashion ... a constitutional quantum of drug use necessary to show a drug problem" (Earls, 2002:836) suggests that the meaning of special needs is not the same in Earls as it was in Vernonia. It is not clear whether the test in Earls has provided a lowered floor or simply eliminated the floor altogether.

It may be argued that Earls created a new and lower floor of evidence to justify testing even if data are anecdotal and based only on teacher observations. However, it can be just as easily argued that the Court's reasoning leaves some doubt as to whether any evidence is required at all. On the one hand, the Court defined its test as not requiring a particularized or pervasive drug problem before allowing suspicionless drug testing, but on the other hand looked for support for drug testing in Treasury Employees v. Van Raab (Van Raab) (1989). In Van Raab, the Court upheld random drug testing for customs inspectors, not because there was individualized or pervasive evidence of drug use, but since they are responsible for stemming the flow of drugs into the country and could reasonably have constituted a safety-sensitive group subject to suspicionless drug tests. More importantly, the Earls Court cited Van Raab for the principle that drug testing can be done on a purely preventive basis. As such, it is unclear whether the Court's standard for the use of a random drug test is a lowered floor whereby school officials must provide some evidence of learner drug use less than 
individualized and pervasive or whether the standard eliminates the floor altogether since testing can be for purely preventive purposes.

Another question that Earls leaves unanswered is whether random drug testing can be extended to all learners in public schools. In an earlier post-Vernonia, but pre-Earls case, a federal trial court in Texas struck down both a universal and random drug test policy for learners in grades six through twelve (Tannahill v. Lockney Indep. Sch. Dist., 2001). If the Supreme Court were to address a similar set of facts now, it is likely that it would come to the same result but for a different reason. The Court would likely find that drug testing of all learners should be subject to T.L.O.'s individualized reasonable suspicion test.

Beyond the question of the appropriate standard is how the results of drug testing are used. The Court thought significant a part of the Earls policy that limited the results of testing to participation in extracurricular activities. Learners in extracurricular activities who tested positive to drugs were not removed from school or reported to law-enforcement authorities. As such, it is unclear whether learners in extracurricular activities can be suspended or expelled from school or whether positive drug test results can be turned over to law-enforcement authorities.

A serious question remains regarding cost limitations for drug testing. As some public school systems are struggling to meet operating expenses in a sluggish economy, one can only wonder how they can afford to test even $10 \%$ of their learners per week, as was the case in Vernonia. In light of cost issues, it is worth noting that at least one school system reported that it spent $\$ 70,000$ per year for weekly random tests of 75 learners' funds that might otherwise have been used for educational programming or staff (Dohrman, 1996; Hawkins, 2000). While school officials could lower the percentage or number of learners tested each week, at some point the number would become so low as to lose its deterrent value. In addition, learners who may not feel singled out when they are part of a larger group selected for testing, may feel more vulnerable and isolated if they are part of a very small number. In the end, school officials, now that they can randomly drug test, must decide whether they will do so at the expense of lost dollars and the possible loss of learners. Further, even if school boards had ample funds available, a question can be raised as to whether drug testing is the most useful way to use district resources in the battle to end reduce, if not eliminate, drug use in schools. 
An assumption of suspicionless drug testing for extracurricular activities is that those activities are not related to the educational programme. The dissent's concern, not addressed earlier in this article, about the relationship between the educational programme and extracurricular activities, is one that schools that choose to test learners randomly will have to face. To this end, it remains to be seen whether learners, even if they know that extracurricular participation may be important in college admissions, refuse to participate if they (and, presumably, their parents) object to random drug testing. If there can be a widespread acceptance among learners for a drug culture, as in Vernonia, it seems there could be a widespread rejection of extracurricular participation if drug testing is required.

\section{Conclusion}

Clearly, while school officials have the authority to develop random drug testing policies, it is likely that many, if not most, will face practical and political problems. Insofar as parent support in creating a policy is crucial, school officials would be wise to garner their assistance before developing a plan. However, even if most parents are supportive, as reflected in Vernonia and Earls, some will undoubtedly still object to any form of testing, regardless of whatever process is used.

Beyond the practical problems such as parental support and costs, is the legal concern that we have probably not seen the end of drug testing litigation in the United States. Given the success of challenges to some drug testing policies under state constitutions (Trinidad Sch. Dist. No. 1 v. Lopez, 1998), one can expect more litigation in this area even as the alarming statistics regarding drug use among middle and high school learners are not likely to decrease. Whether random drug testing actually deters drug use certainly remains to be seen. Even so, as the Earls Court seems to suggest, school officials cannot be faulted for adopting measures that they think will help to eliminate drug use in schools.

In light of the mixed blessings and pitfalls that drug testing may present it remains to be seen whether educational leaders in South Africa will reduce their level of concern about learner privacy and permit testing if drug use spreads, or whether they will adopt a more proactive stance to help eradicate this pernicious practice before it becomes more of a problem. In this regard a leaf or two might be taken from the American book. In the first place the contents of the American Fourth amendment - affording the people a right to be 
secured against unreasonable searches and seizures - shows certain similarities to section 14 of the South African Bill of Rights which determines that everybody has the right to privacy which includes the right not to have property searched and possessions seized (SA, 1996a).

As far as suspicion is concerned, the South African National Policy on the Management of Drug Abuse by Learners (SA, 1996b) specifies that there should be reasonable suspicion. Since the concept of reasonable suspicion has not been determined within the school context, one might learn from the American experience. Reasonable suspicion is not to be seen as being the same high standard of proof as probably needed by the police. Examples such as information provided by a reliable learner or parents or school employees (including teachers) should be enough to constitute reasonable suspicion within the South African context.

The South African National Policy on the Management of Drug Abuse by Learners (SA, 1996b) prohibits random (or so-called suspicionless) searches. In time to come this policy might prove to be overly simplified. In a particular school society where the use of illegal drugs poses a serious threat to the physical safety of learners and/or the security of learning environment, it might be a more sensible approach to make use of random testing - in particular where methods such as urinanalysis or saliva tests - which are minimally intrusive to learner privacy - are applied.

Although strip searches are not specifically mentioned in the South African National Policy on the Management of Drug Abuse by Learners (SA, 1996b) the contents of the provisions indicate that the person of the learner may be searched. Similar to the American approach, these searches are allowed in certain instances. In South Africa, based on reasonable suspicion it has to be carried out by person(s) of "the same gender ... in a decent and orderly manner". Like in the case of ordinary (non-strip) searches the Policy seems to require a person of the learner's choice (such as for example a parent) to be present at the search for support as well as a second witness of the same gender. However, it needs to be added that such a search has to be conducted with utmost care, taking the learner's right to human dignity and right to privacy into careful consideration (SA, 1996a). 


\section{Bibliography}

ANON. 2003. Drug testers have designs on new steroids. Washington Post, March 8, WL 15464675.

DOHRMAN, G. 1996. War on drugs only a skirmish. L.A. Times :C 6, Jan 25.

HAWKINS, D. 2000. Trial by vial. U.S. News \& World Repor, :73, May 31.

IOC STRIPS '02 SKI MEDALS. 2003. Desert News, June 30, WL 60838206.

SA

see SOUTH AFRICA

SOUTH AFRICA. 1996a. Constitution of the Republic of South Africa, 108 of 1996. Pretoria : Government Printers.

SOUTH AFRICA. 1996b. National Education Policy Act, 27 of 1996. Pretoria : Government Printers.

THE CONSTITUTION OF THE UNITED STATES. 1789. Commission on the bicentennial of the United States Constitution : Washington DC.

\section{Case Law}

Acton v. Vernonia Sch. Dist. 47 J, 796 F. Supp.1354 (D. Or. 1992); rev'd, 23 F.3d 1514 (9th Cir. 1994); rev'd sub nom. Vernonia School District $47 \mathrm{~J}$ v. Acton, 515 U.S. 646 (1995); on remand, Acton v. Vernonia Sch. Dist. 47J, 66 F.3d 217, 218 (9th Cir.1995).

Anders ex rel. Anders v. Fort Wayne Community Schs., 124 F. Supp.2d 618 (N.D. Ind. 2000).

Bell v. Marseilles Elementary Sch., 160 F. Supp.2d 833 (N.D. III. 2001).

Bellnier v. Lund, 438 F. Supp. 47 (N.D.N.Y.1977).

Board of Educ. of Indep. Sch. Dist. No. 92 of Pottawatomie v. Earls, 536 U.S. 822 (2002).

Commonwealth v. Carey, 554 N.E.2d 1199 (Mass. 1990).

Commonwealth v. Cass, 709 A.2d 350 (Pa. 1998).

Commonwealth v. Snyder, 597 N.E.2d 1363 (Mass. 1992).

Cornfield v. Consolidated High Sch. Dist. No. 230, 991 F.2d 1316 (7th Cir.1993).

Covington County v. G.W., 767 So. 2d 187 (Miss. 2000).

Cuesta v. School Bd., 285 F.3d 962 (11th Cir. 2002).

Earls v. Board of Educ. of Indep. Sch. Dist. No. 92 of Pottawatomie, 115 F. Supp.2d 1281 (W.D. Okla. 2000); rev'd, 242 F.3d 1264 (10th Cir. 2001), rev'd sub nom., Board of Educ. of Indep. Sch. Dist. No. 92 of Pottawatomie v. Earls, 536 U.S. 822 (2002).

F.S.E. v. State, 993 P.2d 771 (Olka. Ct. Crim. App. 1999).

Hedges v. Musco, 204 F.3d 109 (3d Cir. 2000).

In re D.E.M., 727 A.2d 570 (Pa. Super. Ct. 1999).

In re F.B., 726 A.2d 361 (Pa. 1999).

In re Joseph G., 38 Cal.Rptr. 902 (Cal. Ct. App. 1995).

In re Murray, 525 S.E.2d 496 (N.C. Ct. App. 2000).

In re L.A., 21 P.3d 952 (Kan. 2001).

In re T.L.O., 428 A.2d 1327 (N.J. Juv. \& Dom. Rel. Ct. 1980); aff'd, 448 A.2d

493 (N.J. Super. Ct. App. Div. 1982); rev'd, 463 A.2d 934 (N.J. 1983); rev'd

sub nom., New Jersey v. T.L.O., 469 U.S. 325 (1985).

In the Interest of Isiah B., 500 N.W.2d 637 (Wis. 1993). 
Jenkins v. Tallaedga City Bd. of Educ., 115 F.3d 821 (11th Cir. 1997), cert. denied, sub nom. Jenkins by Hall v. Herring, 522 U.S. 966 (1997).

Joy v. Penn Harris Madison Sch. Corp., 212 F.3d 1052 (7th Cir.2000).

Kennedy v. Dexter Consol. Schs., 10 P.3d 115 (N.M. 2000).

Linke v. Northwestern Sch. Corp., 763 N.E.2d 972 (Ind. 2002).

Matter of Gregory M., 606 N.Y.S.2d 579 (N.Y. 1993).

Miller ex rel. Miller v. Wilkes, 172 F.3d 574 (8th Cir.1999).

New Jersey v. T.L.O., 469 U.S. 325 (1985).

People v. Lanthier, 488 P.2d 625 (1971).

Potts v. Wright, 357 F. Supp. 215 (E.D. Pa. 1973).

Schaill v. Tippecanoe County Sch. Corp., 864 F.2d 1309 (7th Cir. 1988).

State ex rel. Galford v. Mark Anthony B., 433 S.E.2d 41 (W. Va. 1993).

Tannahill v. Lockney Indep. Sch. Dist., 133 F. Supp.2d 919 (N.D. Tex. 2001).

Thomas ex rel. Thomas v. Roberts, 261 F.3d 1160 (11th Cir. 2001).

Todd v. Rush County Schs., 133 F.3d 984 (7 ${ }^{\text {th }}$ Cir. 1998), cert. denied, 525 U.S. 824 (1999).

Treasury Employees v. Van Raab, 489 U.S. 656 (1989).

Trinidad Sch. Dist. No. 1 v. Lopez, 963 P.2d 1095 (Colo. 1998).

Vernonia School District 47 J v. Acton, 515 U.S. 646 (1995).

Williams ex rel. Williams v. Ellington, 936 F.2d 881 (6th Cir.1991).

Willis v. Anderson Community Sch. Corp., 158 F.3d 415 (7th Cir. 1998), cert. denied, 526 U.S. 1019 (1999).

Zamora v. Pomeroy, 639 F.2d 662 (10th Cir.1981).

\section{Key concepts:}

drugs; the illegal use of

learner' rights of privacy

random searches

testing for drugs

\section{Kernbegrippe:}

dwelms; die gebruik van verbode middels

leerdersregte op privaatheid

toetsing vir dwelmgebruik

willekeurige deursoeking

\section{Editorial note}

According to the policy of the Editorial Board of Koers, all articles have to be based on an explicitly formulated philosophical or lifeconceptual framework. While this framework does not need to be Christian or reformational, authors of articles are expected to reflect on their subject material from such a foundational (philosophical, life-conceptual, fundamental, principial) framework, and to use their particular framework as a point of reference or for the purpose of gleaning normative perspectives from it for their discussions. 
In the case of this article, however, the authors did not make such a pertinent attempt to draft an explicit philosophical framework because of the particular scientific paradigm in which they function as scholars. The Editorial Board found that, in the case of this article, while this is not done in a separate section, the reflections of the authors are indeed founded in a certain philosophical perspective, a perspective that is integrated in their discussion of the theme, and expounded in their views on the subject. The interested viewer can judge their views against the backdrop of those expounded in the introductory article to this volume entitled "' $n$ Beginselgrondslag vir gesag, vryheid, orde en dissipline in die onderwysopset van die vroeg-21ste eeu". The author of the latter article outlines a reformational view regarding authority, freedom, order and discipline. The reflections of the author of this specific Koers article can also be evaluated in the light of publications by, for instance, North American authors on discipline such as John van Dyk (cf. his book Letters to Lisa. Conversations with a Christian teacher, 1997; and The craft of Christian teaching, 2000 - both published in Sioux Center by die Dordt College Press), Harro van Brummelen (cf. his books Walking with God in the classroom, 1988 (Burlington : Welch) and Steppingstones to curriculum, 1994 (Seattle :Alta Vistra College Press) and many others. 
